\title{
Eksplorasi Potensi Alami Waduk Menuju Rancangan Wisata Desa Purwosekar Tajinan Kabupaten Malang
}

\author{
Nurin Fitriana ${ }^{* 1}$, Eny Dyah Yuniwati ${ }^{2}$, Azhar Adi Darmawan ${ }^{3}$, Rizalnur Firdaus ${ }^{4}$ \\ $1,2,4$ Universitas Wisnuwardhana Malang \\ ${ }^{3}$ Universitas Muhammadiyah Malang \\ *e-mail : nurin.unidha@gmail.com¹,nieyuniwati@gmail.com²,azhar.wre2001@yahoo.co.id ${ }^{3}$, \\ rizalnurfirdaus@gmail.com ${ }^{4}$
}

\begin{abstract}
The empowerment of village potential is one way to improve the economy. Purwosekar Village, Tajinan Subdistrict, Malang Regency has a reservoir but is not maintained, a lot of garbage, sediment will be a very valuable asset if it is conceptualized by water tourism. Moreover, the village community has a lot of skills and handmade products, thus it is necessary to conceptualize the empowerment of the reservoir to become a tourist place and a means of promoting superior products. The activities carried out are aimed at 1) providing a desain using the SketchUp Pro 3D Tourism reservoir concept 2). Provide stages of activities to develop the potential of village tourism village desain. This dedication activity has an output target in the form of a tourism reservoir desain. So that through this service activities can help disseminate the promotion of products created by the village community.
\end{abstract}

Keywords: desain, reservoir, potency

\begin{abstract}
Abstrak
Pemberdayaan potensi desa adalah salah satu cara meningkatkan perekonomian. Desa Purwosekar Kecamatan Tajinan Kabupaten Malang memiliki waduk akan tetapi tidak terurus, banyak sampah, sedimen akan menjadi aset yang sangat berharga jika dikonsep wisata air. Apalagi masyarakat desa memiliki banyak ketrampilan dan produk handmade, dengan demikian perlu mengkonsep pemberdayaan waduk agar dapat menjadi tempat wisata dan merupakan sarana promosi produk unggulan. Kegiatan yang dilakukan ini bertujuan untuk: 1) memberikan rancangan desain menggunakan Program SkechUp Pro 3D konsep waduk wisata 2). Memberikan tahapan kegiatan untuk pengembangan potensi desa rancangan desa wisata. Kegiatan pengabdian ini memiliki target luaran berupa desain waduk wisata. Sehingga melalui kegiatan pengabdian ini dapat membantu penyebarluasan promosi produk hasil karya masyarakat desa.
\end{abstract}

Kata Kunci: desain, waduk, potensi

\section{PENDAHULUAN}

Kegiatan pemberdayaan masyarakat merupakan suatu pendekatan yang memperhatikan seluruh aspek potensi dalam kehidupan masyarakat tersebut. Sasaran dari kegiatan ini adalah seluruh lapisan masyarakat yang ada dalam wilayah misalnya dalam suatu desa, hal ini sesuai dengan program pemerintah one village one product. Indonesia sedang membangun dalam berbagai bidang khusunya ditumpukan kepada tingkat wilayah Desa (Soleh, 2017). Desa wisata merupakan salah satu program pemberdayaan masyarakat untuk memaksimalkan potensi (Mustangin et al., 2017). Peranan pemerintah desa dalam pemberdayaan masyarakat sangat dominan(Susanti, 2015). Motifnya adalah pemandirian (keberdikarian) yang dapat membangkitkan kemampuan self-help untuk meningkatkan kualitas hidup masyarakat (modernisasi) yang mengacu pada cara berpikir, bagaimana bersikap terhadap perubahan, berperilaku untuk maju. Maka bidang pemberdayaan merupakan titik strategis yang harus diperbarui dan diperluas. Dengan demikian esensi dari pemberdayaan masyarakat di pedesaan adalah pemberdayaan sumberdaya (potensi) lokal yang dapat meningkatkan partisipasi dan memupuk kepedulian semua pihak untuk kemandirian (berdikari) masyarakat. Dampak positif 
dirasakan oleh munculnya banyak pekerjaan baru, peningkatan kesejahteraan, akses jalan yang mudah, pola pikir masyarakat maju(Rahmayanti \& Pinasti, 2018).

Sesuai dengan UU Nomer 6 Tahun 2014 Tentang Desa, Ketentuan Umum Pasal 1 ayat 12, Peraturan Pemberdayaan masyarakat desa adalah upaya mengembangkan kemandirian dan kesejahteraan masyarakat dengan meningkatkan pengetahuan, sikap, keterampilan, perilaku, kemampuan, kesadaran, serta memanfaatkan sumber daya melalui penetapan kebijakan, program, kegiatan, dan pendampingan yang sesuai dengan esensi masalah dan prioritas kebutuhan masyarakat Desa(Suharto, 2018). Setiap desa memiliki potensi baik potensi fisik dan non fisik(Abdurokhman, 2016). Tingginya angka kemiskinan menjadi masalah utama yang dihadapi masyarakat setempat(Sidik, 2015).

Undang Undang Desa diimplementasikan melalui kegiatan pemberdayaan masyarakat, dimana Desa diharapkan mampu membawa perubahan nyata sehingga harkat dan martabat mereka pulih kembali. Pendayagunaan potensi masyarakat merupakan pendekatan yang memperhatikan seluruh aspek kehidupan masyarakat dengan sasaran seluruh lapisan masyarakat, bermotifkan pemandirian (keberdikarian), sehingga mampu membangkitkan kemampuan self-help. Tujuannya untuk meningkatkan kualitas hidup masyarakat (modernisasi) yang mengacu pada cara berpikir, bersikap, berperilaku untuk maju.

Desa Purwosekar Kecamatan Tajinan Kabupaten Malang mempunyai potensi alami yang besar, diantaranya adalah memiliki iklim dan jenis tanah yang baik untuk perkebunan, memiliki luas tanah yang luas,dab beberapa fasilitas umum. Selain itu, desa ini memiliki potensi wisata jika pemberdayaan masyarakatnya dapat dimaksimalkan, adanya sungai yang terhubung pada waduk buatan pemerintah adalah salah satunya.

Tujuan awal waduk buatan yang dibuat oleh pemerintah di desa purwosekar ini sebagai sarana penampung air yang dapat juga berfungsi sebagai media recharge air tanah serta penunjang pengairan area pertanian. Hal ini sangat penting terhadap keberlangsungan ketahanan pangan. Sesuai isu terbaru pemerintah tentang ketahanan pangan bagi masyarakat indonesia. Namun, waduk di Desa Purwosekar Kecamatan Tajinan Kabupaten Malang tidak berfungsi kembali bahkan mengalami kerusakan, yaitu macetnya aliran air waduk ke lahan pertanian disebabkan semakin banyaknya tumbuh tanaman liar, sampah, bahkan semakin banyaknya sedimen. Fungsi pengairan waduk terhambat, sehingga terjadi penurunan hasil panen karena kekeringan. Padahal apabila waduk diolah dengan baik dapat meningkatkan perekonomian desa. Gambar berikut menunjukkan kondisi waduk saat ini:

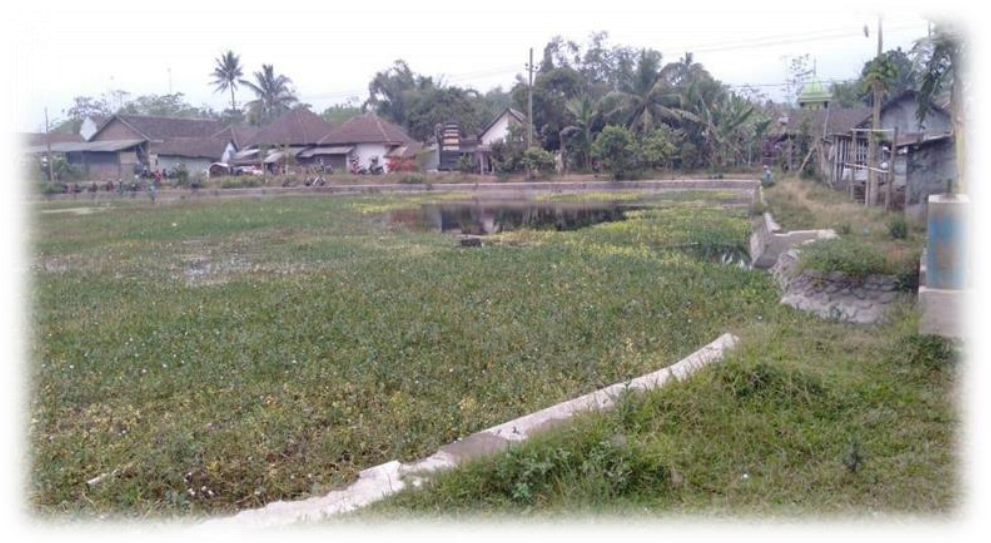

Gambar 1. Kondisi Waduk yang tidak terurus

Kondisi waduk yang terbengkalai menjadikan berkurangnya fungsi waduk dan Hal ini menjadikan berkurangnya fungsi waduk dan menjadikan tempat terlihat kotor dan kumuh. Selain itu, potensi sumber daya manusia di desa purwosekar barmacam-macam diantaranya sudah adanya produk olahan jamu kunir asem yang sudah dijual ke luar daerah, adanya beberapa hasil kebun yang melimpah seperti singkong, sukun dan yang lainnya. Hal ini menjadi potensi 
tersendiri saat pemberdayaan warga dapat dimaksimalkan. Pentingnya promosi potensi yang dimiliki dapat mengembangkan pendapatan (Susilawati, 2017). Pemerintahan desa perlu diberikan wawasan dan pengetahuan bagaimana menggali potensi dan permasalahan yang ada didesa agar bisa memetakan persoalan desa (Prahati et al., 2017).

\section{METODE}

Pemberdayaan masyarakat pada prinsipnya yaitu menerapkan hasil pengembangan ilmu pengetahuan dan teknologi, teknologi tepat guna, dan temuan baru untuk kemajuan ekonomi dan pertanian masyarakat desa. Meningkatkan kualitas pemerintahan dan masyarakat desa melalui pendidikan, pelatihan, dan penyuluhan. Dan pemberdayaan masyarakat mengakui dan memfungsikan institusi asli dan/atau yang sudah ada di masyarakat Desa. Pengembangan potensi wisata berbasis masyarakat merupakan upaya strategis untuk mengembangkan masyarakat(Komariah et al., 2018).

Kegiatan dilaksanakan di Desa Purwosekar, Kecamatan Tajinan, Kabupaten Malang, Jawa Timur. Kegiatan pengabdian dilakukan dengan metode kualitatif menggunakan pendekatan deskriptif analitis. Sumber untuk data yang diperoleh dengan model kualitatif adalah kata dan tindakan, dan kemudian penambahan seperti foto lapangan, catatan, dan karya serupa. Terkait dengan data, maka dapat menggambarkan jenis data dalam kata-kata serta apa yang dilakukan, sumber tertulis, dokumentasi dan hasil bersama (Subandi, 2011). Dalam kegiatan ini, model pengumpulan data yang digunakan adalah wawancara mendalam dan wawancara dengan informan di delapan desa sampel dan pengamatan langsung terhadap objek penelitian(Krippendorff, Klaus, Wajidi, 1993).

Kegiatan diawali dengan merancang konsep perahu menggunakan program SketchUp Pro 3 dimensi. Kemudian, pembuatan perahu dengan bahan-bahan yang telah didiskusikan Bersama warga untuk memastikan ketahanan dan kekuatan penanampungannya. Setelah itu, dilakukan gotong-royong pembersihan area waduk.

\section{HASIL DAN PEMBAHASAN}

Pembangunan daerah merupakan suatu keharusan, namun pembangunan daerah juga harus bermanfaat bagi masyarakat daerah, baik secara langsung maupun tidak langsung(Yekti, 2017). Partisipasi masyarakat lokal menjadi kunci strategis untuk dapat diberdayakan dan disinergiskan dengan komponen lainnya (Brontowiyono et al., 2016). Kini lingkungan perdesaan dengan segala potensi yang dimilikinya memiliki peluang menjadi daya tarik sebagai daerah wisata. (Sudirah, 2015). Desa Purwosekar Kecamatan Tajinan memiliki beberapa fasilitas umum yang biasa dimanfaatkan oleh warga yaitu terdapat fasilitas keagamaan seperti masjid langgar. Sedangkan fasilitas kesehatan tersedia puskesmas/pustu, posyandu, praktek dokter dan bidan. Sementara itu, untuk fasilitas pendidikan mulai dari TK, SD, SMP, SMA, dan MA (Buku Profil Desa Purwosekar Kecamatan Tajinan Kabupaten Malang, 2019).

Kepada Desa menyampaikan pula tentang terdapatnya waduk buatan pemerintah propinsi yang dahulunya digunakan untuk pengairan sawah akan tetapi saat ini keberadaan waduk sudah mulai tidak terurus. Warga kurang mengurus kebersihan dan kelestarian waduk. Hal ini ditandai semakin banyaknya tumbuh eceng gondok dipermukaan waduk, dan juga semakin banyaknya lumpur dalam dasar waduk dan terkadang ada warga yang membuang sampah disana. Perencanaan perbaikan waduk terdapat pada perencanaan desa.

Air adalah sumberdaya alam yang dinamik (dynamic resources) yang harus dijaga kebersihannya (Suharti, 2014). Sedimentasi pada perairan terjadi karena erosi pada tepi sungai ataupun saluran yang membawa air ke waduk. Tanah dan material organik lainnya masuk ke aliran yang menyebabkan terjadinya pengendapan di dasar. Hal itu terjadi karena saat ini vegetasi 
di tepian hulu sungai semakin sedikit karena adanya degradasi hutan dan betonisasi. Sehingga kemampuan tanah untuk menyerap air hujan menjadi menurun dan mengakibatkan erosi. Pendangkalan sungai yang membuat aliran sungai menjadi lebih deras sampai ke hilir. Hal tersebut membuat peningkatan debit air sungai dan berpotensi menyebabkan banjir.

Upaya pengelolaan waduk untuk menjaga kualitas air dapat dilakukan dengan mengendalikan waduk dengan beberapa strategi(Susanti \& Sasongko, 2012). Hal Ini dapat menjadikan potensi ketika pemberdayaan masyarakat dapat dimaksimalkan. Dengan beberapa potensi yang dapat dikembangkan dapat digunakan untuk mempromosikan potensi daerah sehingga dapat diketahui oleh masyarakat luar maka nantinya dapat meningkatkan pendapatan daerah (Yekti, 2017). Akan tetapi kurangnya upaya promosi dari masyarakat menjadikan susahnya penjualan produk unggulan daerah (Fitriana, 2019).

Potensi desa dapat berupa sumber daya alam dan sumber daya manusia, khususnya untuk potensi alam harus lebih dieksplorasi dan dikembangkan sebagai salah satu desa wisata yang bisa diandalkan. Ekowisata dapat dilihat sebagai suatu konsep pengembangan pariwisata berkelanjutan(Saifullah \& Harahap, 2015). Desa wisata akan memberikan dampak positif bagi perekonomian desa. Pengembangan desa wisata diyakini akan memberi dampak positif bagi perkembangam desa. Seperti waduk di Desa Purwosekar ini merupakan potensi alam yang bisa dikembangkan sebagai destinasi ekowisata.

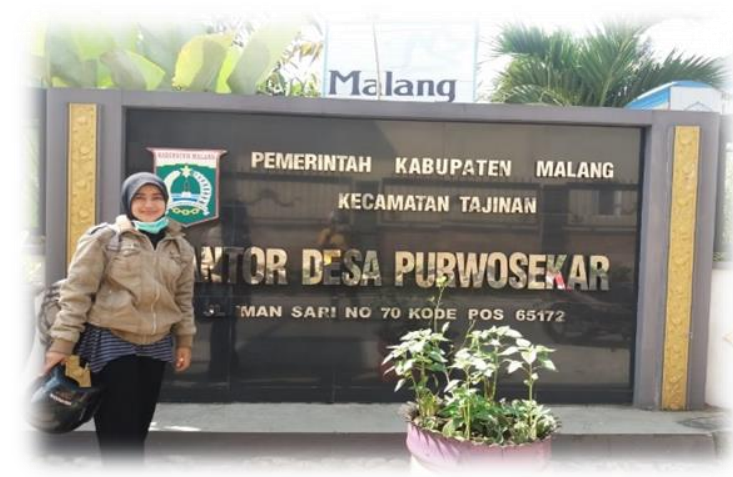

(a)

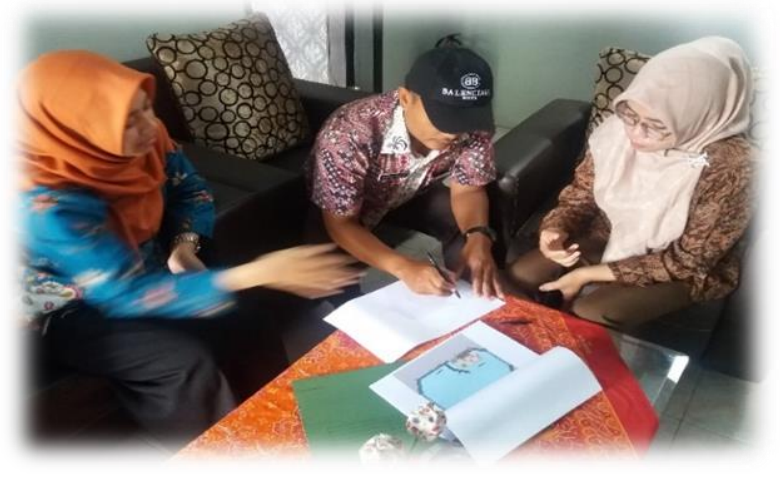

(b)

Gambar 2. Lokasi Pengabdian (a) koordinasi Tim dengan Kepala Desa (b)

Berdasarkan hasil diskusi Tim Pengabdian Universitas Wisnuwardhana Malang dengan mitra desa diperoleh beberapa rancangan kerja yang akan dilaksanakan untuk pengembangan potensi Desa yang terintegrasi.

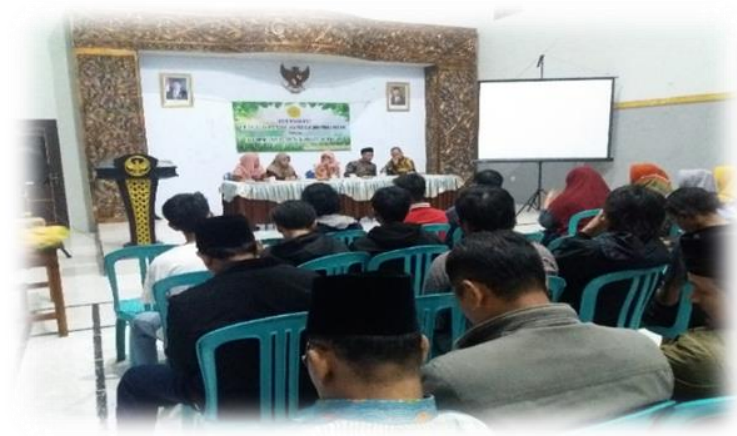

(a)

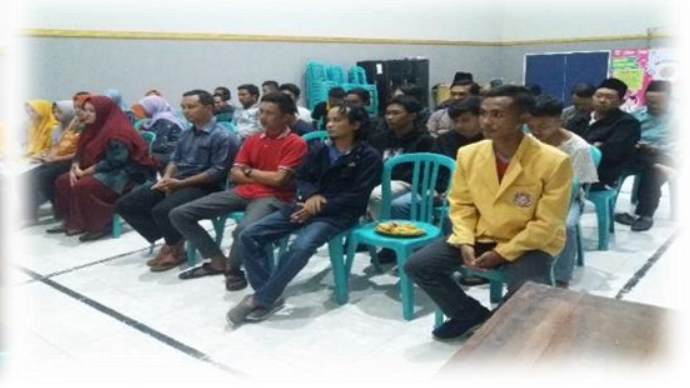

(b)

Gambar 3. Sosialisasi program (a) keikutsertaan mahasiswa dan karangtaruna (b) 


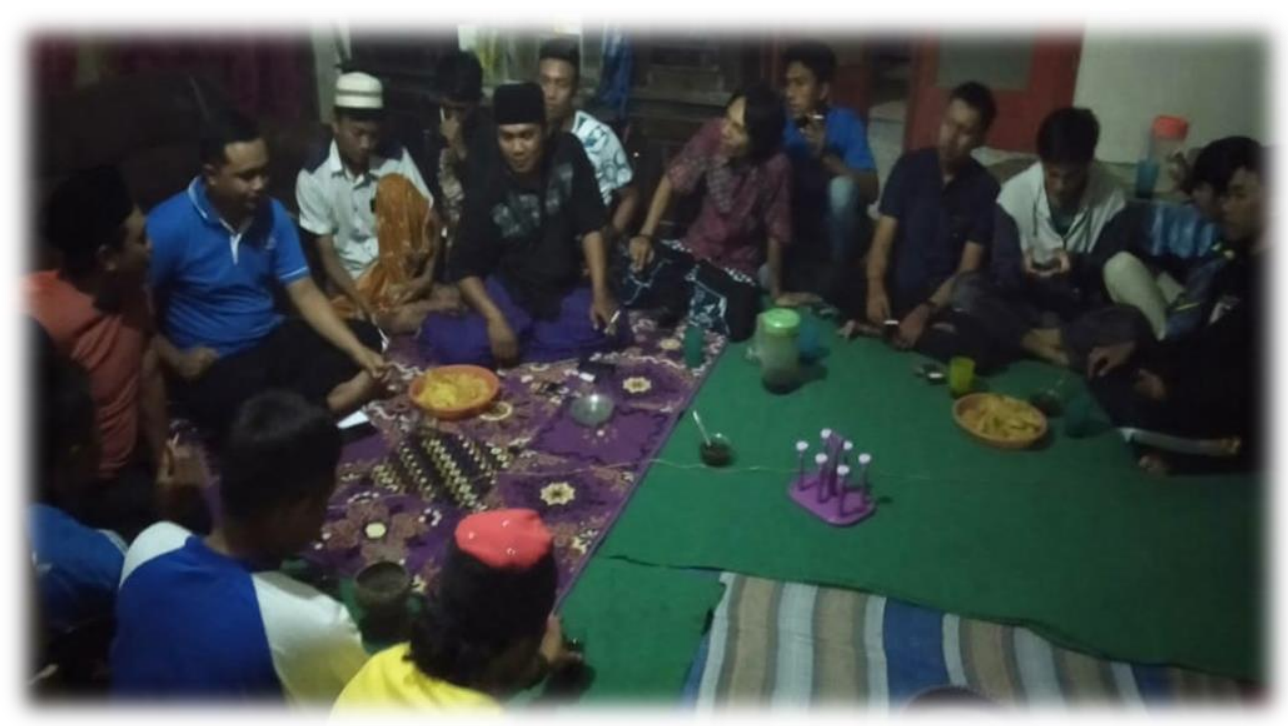

Gambar 4. Koordinasi dengan Karangtaruna

Kegiatan Koordinasi Tim Pengabdian masyarakat dengan pihak karang taruna desa Purwosekar Kecamatan Tajinan bertujuan untuk membuat skala prioritas pengerjaan yang akan dilaksanakan. Langkah awal adalah dengan merancang pembuatan perahu sederhana untuk pembersihan sampah dalam waduk.

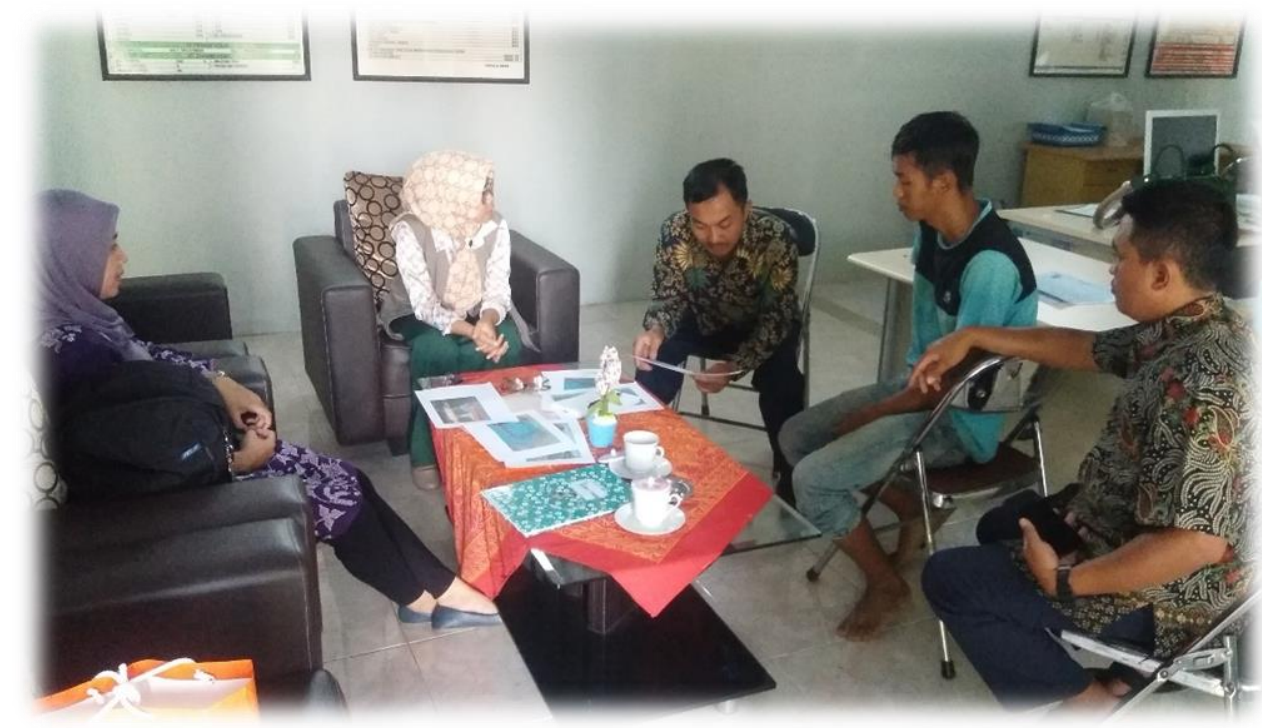

Gambar 5. Diskusi pembuatan transportasi air sederhana dengan perangkat desa

Berdasarkan hasil diskusi diperoleh rancangan desain perahu sederhana untuk alat transportasi air pembersihan sedimen, sampah dan tumbuhan liar dalam waduk. Dengan Program SkechUp Pro 3D Desain, diperoleh rancangan sebagai berikut: 


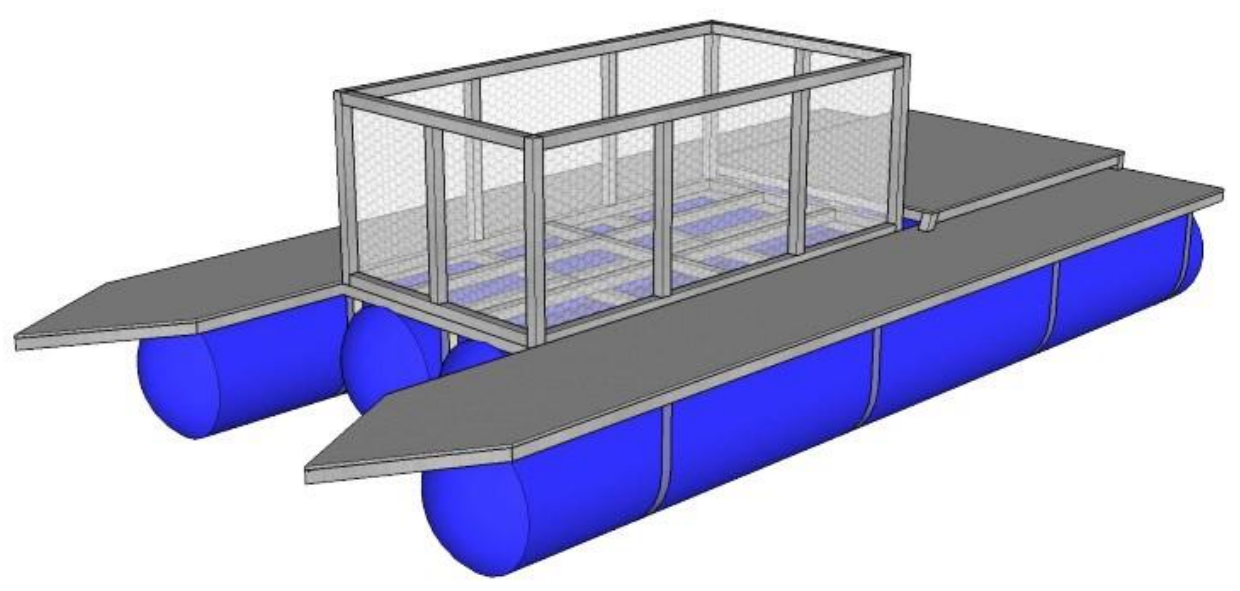

Gambar 6. Desain perahu sampah sederhana Program SkechUp Pro 3D Desain

Perahu ini digunakan sebagai sarana transportasi air dalam rangka mempermudah pembersihan area waduk membersihkan waduk dari sedimen dan enceng gondok liar, sampah dan lumpur. Perahu ini nantinya akan dirakit sendiri oleh karangtaruna yang beberapa komponennya menggunakan bahan bekas seperti tong bekas dan lainnya.

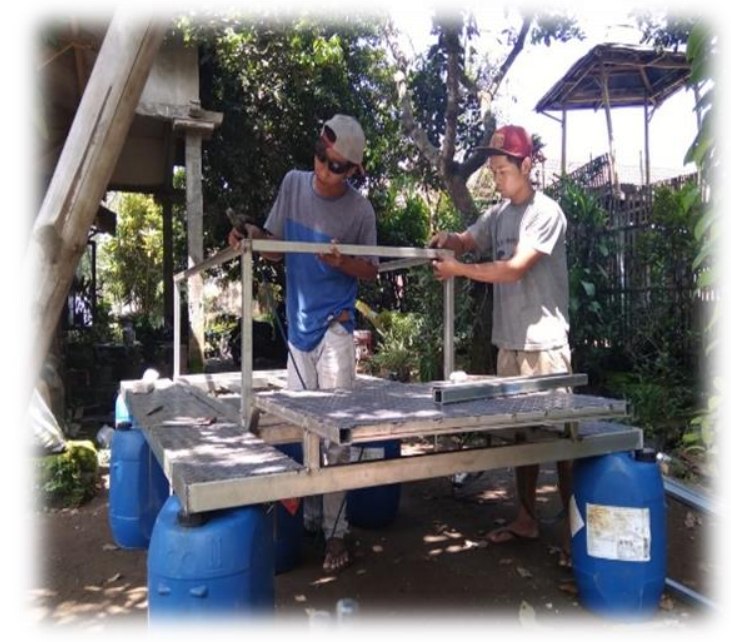

(a)

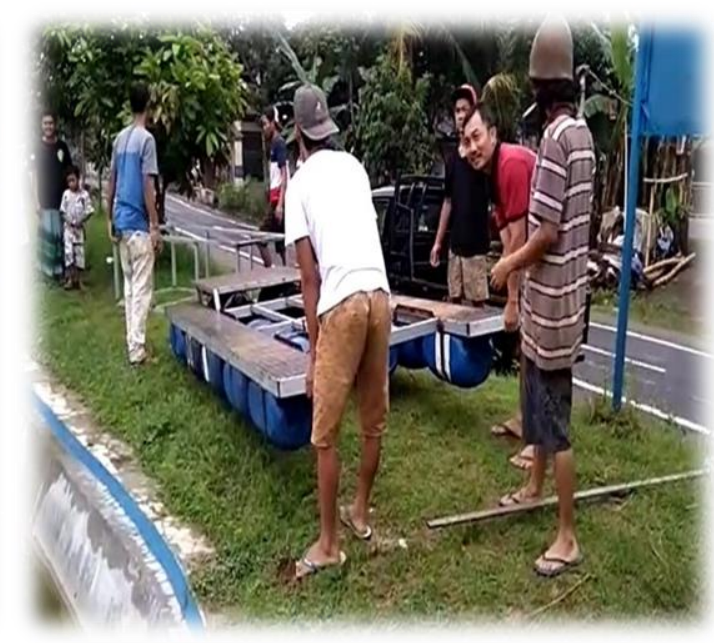

(b)

Gambar 7. Warga menbuat perahu sampah sederhana (a) uji coba perahu sampah (b)

Setelah konsep rancangan jadi maka, warga membuat dan melakukan uji coba perahu penampung sampah dan sedimen yang akan digunakan warga untuk membersihkan area waduk. Selain itu Tim pengabdian masyarakat juga memfasilitasi keinginan pihak desa untuk merancang gambar untuk konsep wisata yang akan dikembangkan setelah kegiatan pembersihan waduk selesai. Rancangan konsep wisata waduk yang akan dikembangkan, yaitu: 


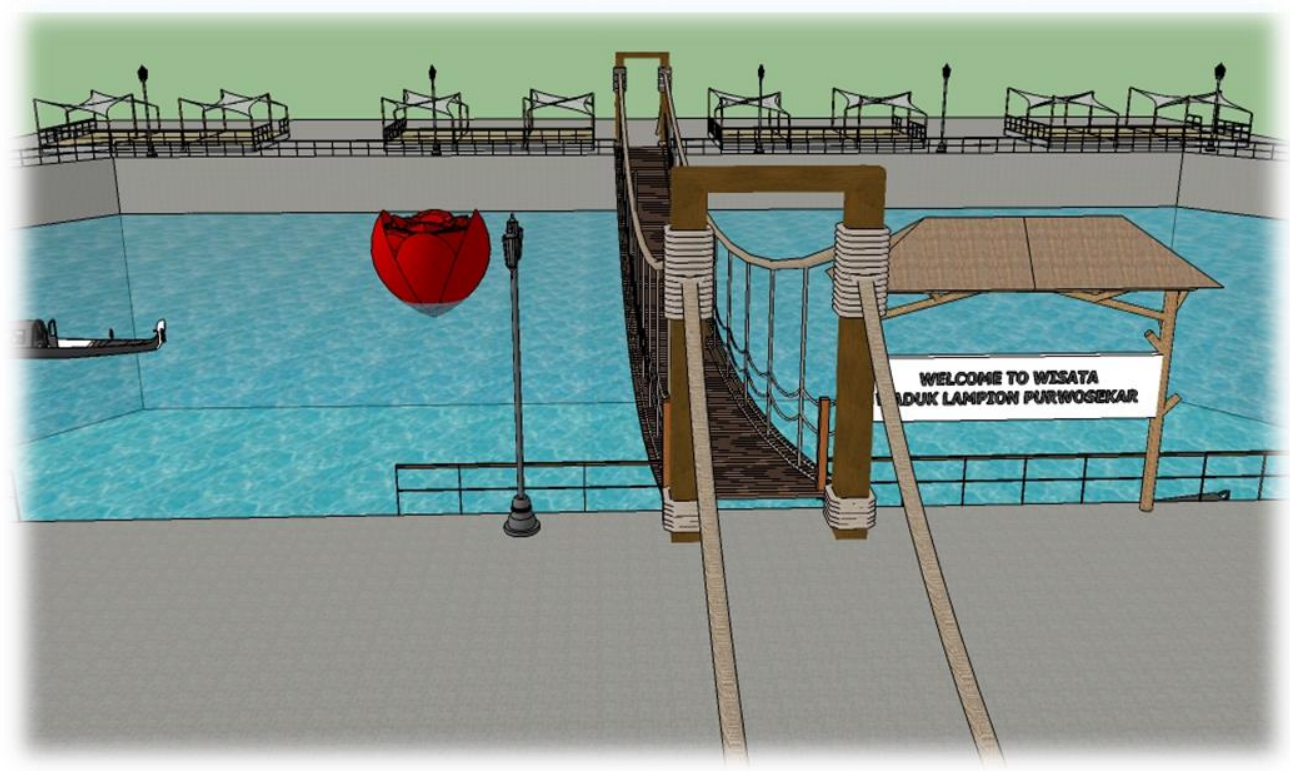

Gambar 8. Rancangan desain konsep pintu masuk waduk wisata

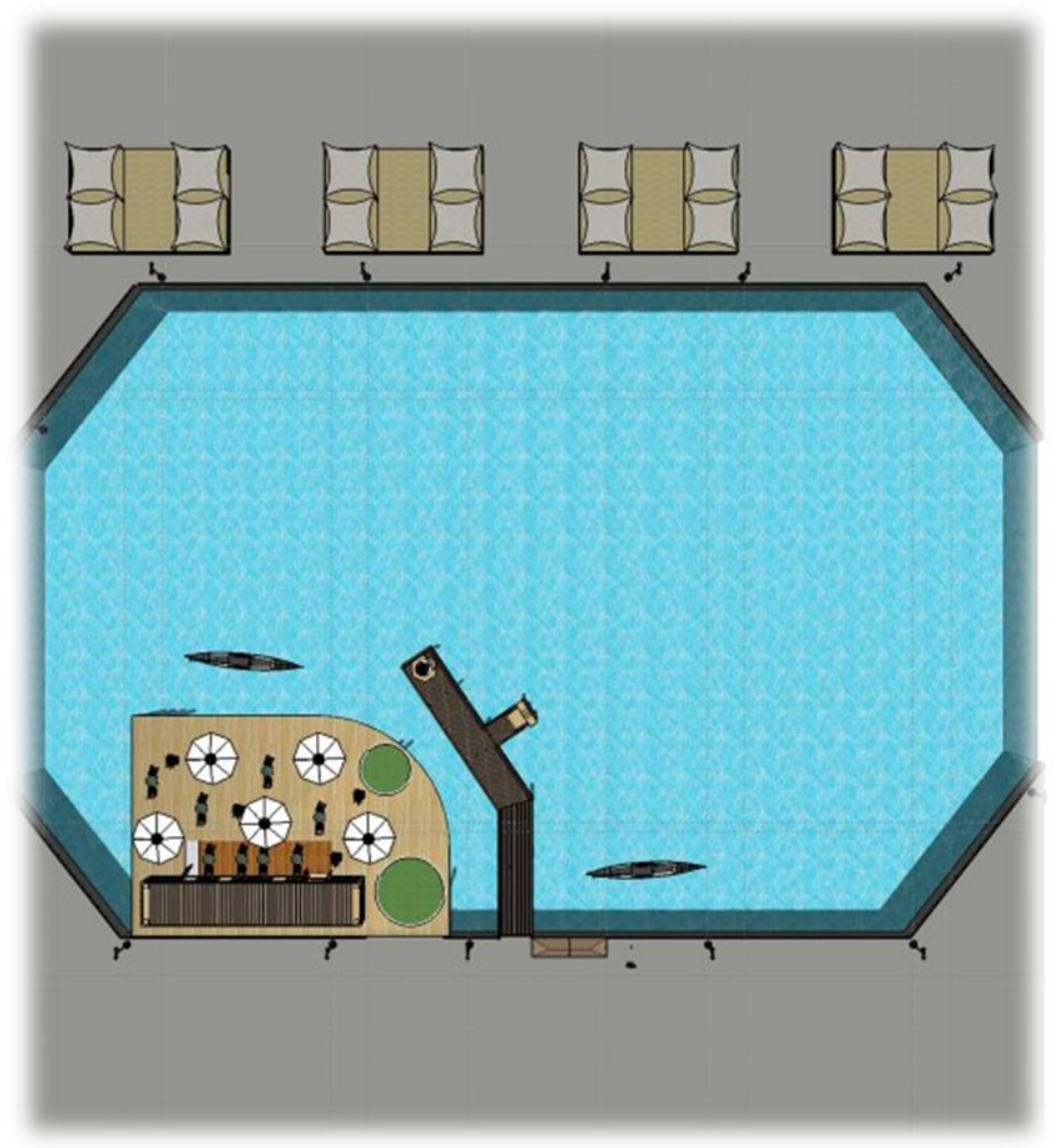

Gambar 9. Rancangan desain konsep keseluruhan waduk wisata 


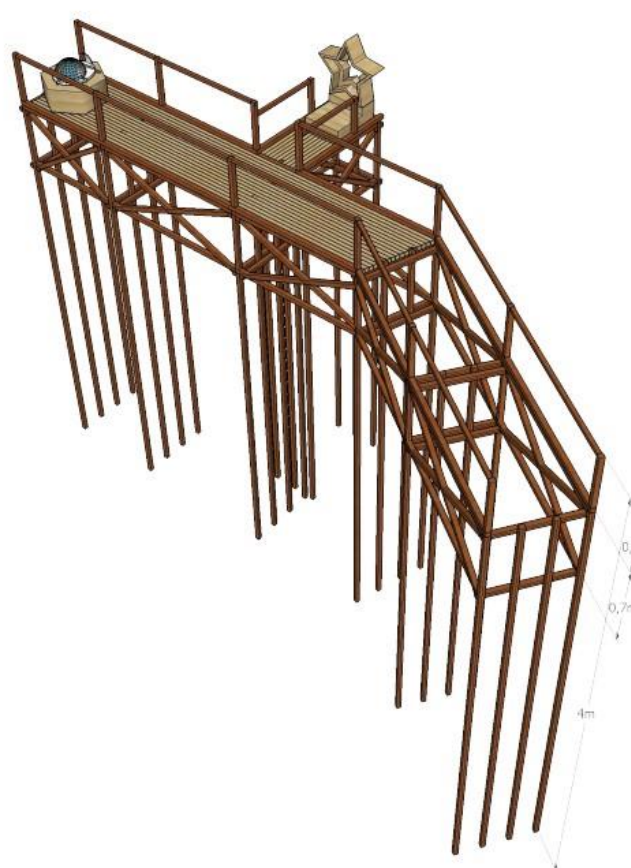

Gambar 10. Konstruksi jembatan spot foto

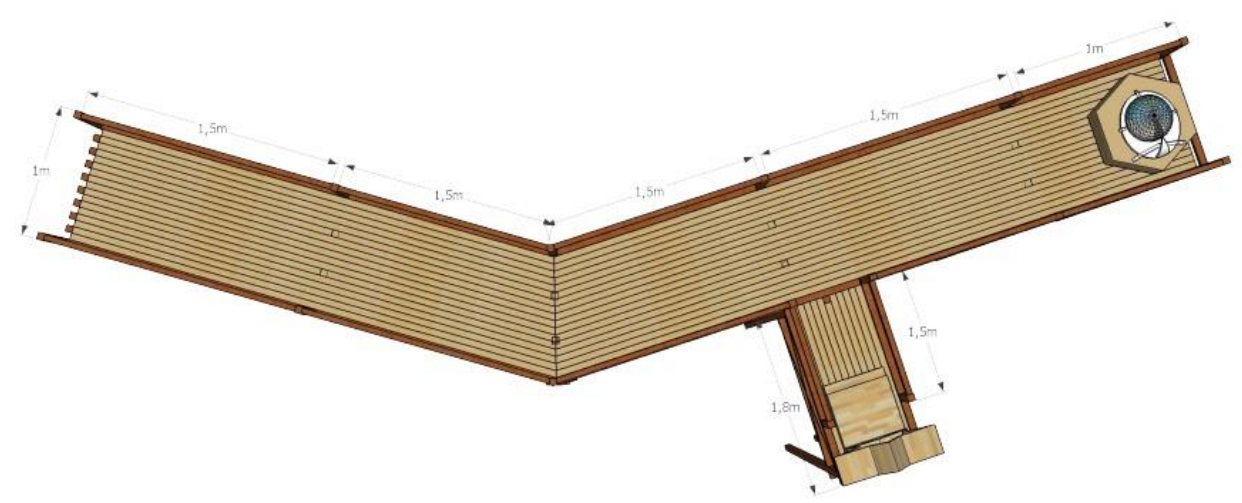

Gambar 11. Konstruksi jembatan tampak atas

Untuk Langkah awal, warga dan karangtaruna sudah memulai pembersihan area sungai aliran waduk. Untuk membersihkan kotoran sampah, sedimen sampai pada perapian pohonpohon yang sudah mulai tidak terurus. 


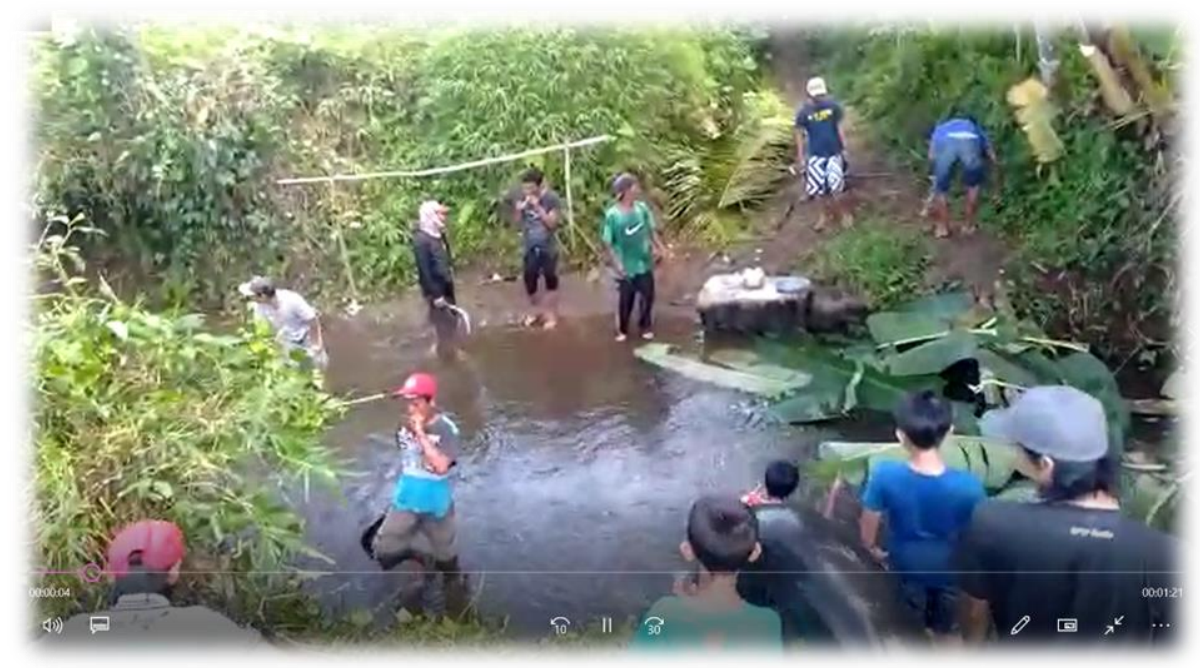

Gambar 12 Gotong royong pembersihan sungai aliran waduk

\section{KESIMPULAN}

Kegiatan program pengabdian masyarakat yang dilaksanakan berjalan dengan baik adanya partisipasi dan swadaya masyarakat dalam perencanaan dan pelaksanaan kegiatan pemberdayaan masyarakat memiliki peran besar. Selain itu, rancangan konsep desa wisata menjadi daya tarik tersendiri apabila desa dapat mengeksplorasi potensi desa yang dimiliki. Tempat wisata yang dikembangkan juga dapat digunakan sebagai tempat penjualan hasil produksi krativitas warga sehingga dapat meningkatkan perekonomian desa. Dampak positif dari kegiatan ini adalah membuka wawasan warga untuk menggali potensi dan mengembangankan produk unggulan yang lainnya sehingga dapat mendukung kegiatan promosi dalam rancangan wisata nantinya. Dengan demikian jika banyak pengunjung dan lebih dikenal akan memungkinkan terlaksananya peningkatan perekonomian desa.

\section{UCAPAN TERIMAKASIH}

Tim Pengabdian Masyarakat mengucapkan terimakasih kepada Kepala Desa dan warga desa Purwosekar atas kerjasamanya dalam program pemberdayaan masayarakat yang dilakssanakan. Dan ucapan terimakasih pada Kemenristek-BRIN yang telah mendanai kegiatan ini.

\section{DAFTAR PUSTAKA}

Abdurokhman. (2016). Pengembangan potensi desa. Widyaiswara Pada Kantor Diklat Kabupaten Banyumas.

Brontowiyono, W., Lupiyanto, R., \& Wijaya, D. (2016). Pengelolaan Kawasan Sungai Code Berbasis Masyarakat. Jurnal Sains \&Teknologi Lingkungan. https://doi.org/10.20885/jstl.vol2.iss1.art2

Buku Profil Desa Purwosekar Kecamatan Tajinan Kabupaten Malang. (2019).

Fitriana, N. (2019). Implementasi Desain 'Name Board' Desa Wisata Jambu Gondangmanis Kabupaten Jombang. Jurnal Pengabdian Masyarakat Progresif Humanis Brainstorming. https://doi.org/10.30591/japhb.v2i1.1288

Komariah, N., Saepudin, E., \& Yusup, P. M. (2018). Pengembangan Desa Wisata Berbasis Kearifan Lokal. Jurnal Pariwisata Pesona, 3(2). https://doi.org/10.26905/jpp.v3i2.2340 
Krippendorff, Klaus, Wajidi, F. (1993). Analisis isi: pengantar teori dan metodologi (1st ed.). Jakarta: Citra Niaga Rajawali Pers.

Mustangin, Kusniawati, D., Setyaningrum, B., Prasetyawati, E., \& Islami, N. P. (2017). Pemberdayaan Masyarakat Berbasis Potensi Lokal Melalui Program Desa Wisata di Desa Bumiaji. Sosioglobal: Jurnal Pemikiran Dan Penelitian Sosiologi. https://doi.org/10.24198/jsg.v2i1.15282

Prahati, P., Zuhdi, S., \& Aguswan, A. (2017). Penyuluhan Penyusunan Rencana Pembangunan Desa di Desa Kuapan Kecamatan Tambang Kabupaten Kampar. Dinamisia: Jurnal Pengabdian Kepada Masyarakat. https://doi.org/10.31849/dinamisia.v1i1.410

Rahmayanti, Y. D., \& Pinasti, V. I. S. (2018). Dampak Keberadaan Objek Wisata Waduk Sermo Terhadap Perubahan Sosial Ekonomi Masyarakat di Sremo, Kulon Progo, Daerah Istimewa Yogyakarta. Jurnal Pendidikan Sosiologi.

Saifullah, \& Harahap, N. (2015). Strategis Pengembangan Wisata Mangrove di "Blok Bedul"Taman Nasional Alas Purwo Kabupaten Banyuwangi Jawa Timur. Jurnal of Indonesian Tourism and Development Studies.

Sidik, F. (2015). Menggali Potensi Lokal Mewujudkan Kemandirian Desa. JKAP (Jurnal Kebijakan Dan Administrasi Publik). https://doi.org/10.22146/jkap.7962

Soleh, A. (2017). Strategi Pengembangan Potensi Desa. Jurnal Sungkai.

Subandi. (2011). Deskripsi Kualitatif Sebagai Satu Metode Dalam Penelitian Pertunjukan. Harmonia - Journal of Arts Research and Education. https://doi.org/10.15294/harmonia.v11i2.2210

Sudirah. (2015). Modal Sosial dan Pemberdayaan Masyarakat Desa Wisata. Prosiding Seminar Nasional Fakultas Ilmu Sosial Dan Ilmu Politik, Universitas Terbuka UTCC, 26 Agustus 2015.

Suharti, T. (2014). Pengelolaan Sungai, Danau dan Waduk untuk Konservasi Sumberdaya Air. Makalahah Falsafah Sains, Pps 702, 19.

Suharto. (2018). Pemberdayaan Masyarakat Desa Dalam Implementasi Uu Desa (Analisis Implementasi UU No.6 Tahun 2014 Tentang Desa). Prosiding Senas POLHI Ke-1.

Susanti. (2015). Peranan Pemerintah Desa Dalam Pemberdayaan Masyarakat Di Desa Sukamaju Kecamatan Tenggarong Seberang. Jurnal Ilmu Administrasi Negara, 3(3), 898-912.

Susanti, I. T., \& Sasongko, S. B. (2012). Trophic status of Balikpapan city manggar reservoir and its management strategy. Jurnal PRESIPITASI.

Susilawati. (2017). Strategi Pemberdayaan Masyarakat Di Kawasan Jatigede Oleh Pemerintah Kabupaten Sumedang. Jurnal JPPDP. https:journal.ipdn.ac.id.

Yekti, G. I. A. dan S. (2017). Pemberdayaan Masyarakat Dan Potensi Wilayah Di Sekitar Waduk Pitaloka Berbasis Teknologi Informasi Dan Umkm Menuju Desa Curah Cottok Yang AgroEko-Wisata. Seminar Nasional Hasil Pengabdian Kepada Masyarakat 2017. https://semnas.unikama.ac.id. 